УДК. 37.04

ORCID: https://orcid.org/0000-0001-9373-7121

ORCID: https://orcid.org/0000-0002-6720-5954

https://doi.org/10.33296/2707-0255-9(17)-04

\title{
РЯБОВА ЗОЯ,
}

доктор педагогічних наук, професор, завідувач кафедри менеджменту освіти та права ЦІПО ДЗВО «Університет менеджменту освіти», м. Київ, Україна.

\section{БАРАНЦОВА ТЕТЯНА,}

урядова уповноважена з прав осіб з інвалідністю, аспірантка кафедри менеджменту освіти та права ЦІПО ДЗВО «Університет менеджменту освіти», м. Київ, Україна.

\section{АДАПТИВНІ ЗАСАДИ УПРАВЛІННЯ РОЗВИТКОМ ІНКЛЮЗИВНОГО ОСВІТНЬОГО СЕРЕДОВИЩА В ЗАКЛАДАХ ЗАГАЛЬНОЇ СЕРЕДНЬОЇ ОСВІТИ}

Анотація. Стаття присвячена питанням управління розвитком інклюзивного освітнього середовища в закладах загальної середньої освіти на адаптивних засадах. У тексті наводяться сутнісні характеристики інклюзивного освітнього середовища, зазначається, що в основі створення такого середовища в закладі загальної середньої освіти покладено визначення й урахування в освітньому процесі індивідуальних потреб та можливостей кожного здобувача освіти, зокрема учнів з особливими освітніми потребами. Обгрунтовується, що в умовах забезпечення рівного доступу до якісної освіти, зазначене питання $\epsilon$ актуальним, що підсилюється як міжнародними зобов'язаннями, так i нормативними документами. Авторами зазначається, що розвиток інклюзивного освітнього середовища в закладах загальної середньої освіти передбачає позитивну динаміку залучення та включення до освітнього процесу всіх його учасників. Також, наводиться авторське тлумачення поняття «управлінням розвитком інклюзивного освітнього середовища в закладах загальної середньої освіти на адаптивних засадах: це цілеспрямований вплив на процес спільного навчання, виховання та розвитку здобувачів освіти на основі ефективного залучення та включення до освітнього процесу всіх його учасників 3 врахуванням їх потреб й можливостей. Визначається, що перспективною технологією управління розвитком інклюзивного освітнього середовища в закладах загальної середньої освіти на адаптивних засадах $є$ технологія кейс- 
менеджменту. Наводиться іï сутність як певного процесу, який об'єднує оцінку, планування, відстеження успішності навчання та активне залучення до перебігу освітнього процесу, що відповідає потребам як здоров'я здобувача освіти, так і його соціального благополуччя. Стаття також включає описання сутності та етапів соціального супроводу. Авторами наводяться дві освітні програми, опанування змістом яких сприятиме успішному управлінню розвитком інклюзивного освітнього середовища в закладах загальної середньої освіти на адаптивних засадах.

Ключові слова: управління розвитком, інклюзивне освітне середовище, адаптивні засади, кейс-менеджмент, соціальний супровід.

\section{Вступ.}

В умовах забезпечення рівного доступу до якісної освіти, актуальним постає питання створення інклюзивного освітнього середовища в закладах загальної середньої освіти (далі 3ЗСО) та управління його розвитком, зокрема на адаптивних засадах. Актуальність даного питання підсилюється нормативними документами. Так, у Законі України «Про освіту» серед переліку основних засад державної політики у сфері освіти та принципів освітньої діяльності зазначається й розвиток інклюзивного освітнього середовища, у тому числі у закладах освіти, найбільш доступних і наближених до місця проживання осіб 3 особливими освітніми потребами та забезпечення універсального дизайну і розумного пристосування [6]. У Статті 20 Закону України «Про повну загальну середню освіту» зазначено, що система освіти України будується на принципах недискримінації, врахування багатоманітності людини, ефективного залучення та включення до освітнього процесу всіх його учасників [7]. Крім того, у Конституції України закріплено забезпечення права кожної дитини на освіту. Такий напрям розвитку системи освіти України підсилюється і євроінтеграційними процесами, через ратифікацію Україною міжнародних документів, зокрема «Конвенція ООН про права дитини», безпосередньо, стаття 23 та «Конвенція ООН про права осіб з інвалідністю», стаття 24 [3]. 
Таким чином, зазначене обумовлює актуальність та необхідність дослідження питання управління розвитком інклюзивного освітнього середовища в $33 \mathrm{CO}$.

Аналіз останніх досліджень і публікацій. Сутнісні аспекти управління в освіті, у т.ч. й на адаптивних засадах відображено в роботах таких науковців як Н. Білик, А. Большукіна, Т. Борова, В. Гладкова, В. Григораш, Г. Сльникова, Г. Кравченко, Л. Лузан, Н. Любченко, Г. Полякова, О. Почуєва, В. Олійник, 3. Рябова, Л. Сергеєва, Т. Сорочан, Т. Хлєбнікова та ін. Становлення і розвиток інклюзивного навчання відображено в роботах таких науковців, як Л. Байда, Л. Гречко, Л. Даниленко, В. Засенко, Р. Козенко, А. Колупаєва, Ю. Найда, Н. Софій, В. Шелухін та ін. Технологія кейс менеджменту описана в роботах Г. Бевз, К. Віцукаєвої, О. Савчука, К. Сініциної, М. Міровської та ін.

Метою статmі є описання сутності кейс-менеджменту як технології управління розвитком інклюзивного освітнього середовища в ЗЗСО на адаптивних засадах.

\section{Виклад основного матеріалу дослідження.}

Сутність інклюзивного освітнього середовища трактується як «сукупність умов, способів і засобів їх реалізації для спільного навчання, виховання та розвитку здобувачів освіти з урахуванням їхніх потреб та можливостей» [6]. Тобто, в основі створення такого середовища в $33 С О$ покладено визначення й урахування в освітньому процесі індивідуальних потреб та можливостей кожного здобувача освіти, зокрема учнів з особливими освітніми потребами. А розвиток такого середовища передбачає позитивну динаміку залучення та включення до освітнього процесу всіх його учасників. Ураховуючи зазначене,

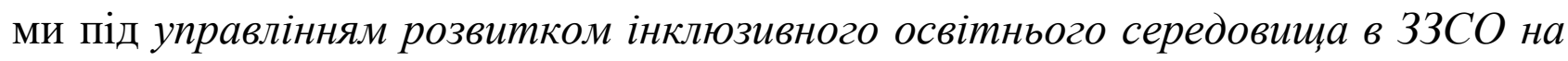
адаптивних засадах будемо розуміти цілеспрямований вплив на процес спільного навчання, виховання та розвитку здобувачів освіти на основі ефективного залучення та включення до освітнього процесу всіх його учасників

\footnotetext{
(C) Украйнська інженерно-педагогічна академія

(С) ГО «Школа адаптивного управління соціально-педагогічними системами»

(C) Рябова 3., Баранцова T.
} 
3 врахуванням їх потреб й можливостей. Саме врахування потреб i можливостей учасників освітнього процесу та активне залучення кожного до його перебігу й визначає сутність адаптивних засад управління розвитком інклюзивного освітнього середовища в закладах загальної середньої освіти $[1 ; 3]$.

Перспективною технологією управління розвитком інклюзивного освітнього середовища в $33 \mathrm{CO}$ на адаптивних засадах $є$ технологія кейсменеджменту (від англ. case management, pобота з випадком, або соціальний супровід). Спираючись на визначення Товариства Кейс-менеджменту Америки (Case Management Society of America) [11], можна дати таке тлумачення цієї дефініції: це певний процес, який передбачає надання послуг клієнту через допомогу і його підтримку на основі спілкування і пошуку доступних ресурсів для досягнення якісних i рентабельних результатів, зокрема успішності в навчанні. Цей процес об’єднує оцінку, планування, відстеження успішності навчання та активне залучення до перебігу освітнього процесу, що відповідає потребам як здоров'я здобувача освіти так і його соціального благополуччя. У зв’язку із зазначеним, можна стверджувати, що ця технологія сприятиме успішному управлінню розвитком інклюзивного освітнього середовища в ЗЗСО на адаптивних засадах [1].

Використовуючи подану технологію, можна управляти процесом розвитку інклюзивного освітнього середовища в З3СО. Це відбуватиметься шляхом отримання інформації про стан учасників освітнього процесу та їх залучення до цього процесу. У разі виявлення проблем, або з'ясування потреби в певній допомозі, або у ситуаціях ризику зниження як фізичного здоров’я, так й освітнього (соціального) потенціалу, чи стану, в якому вони опинилися, застосовується зазначена технологія. Технологія кейс-менеджменту реалізується шляхом включення клієнта (у нашому випадку здобувача освіти 3 особливими освітніми потребами) у процес планування для вирішення власних 
проблем, але 3 консультативною допомогою команди фахівців та батьків дитини [4;5]. Це обумовлює визначення технології кейс-менеджменту як перспективного засобу розроблення певної сукупності вказівок, що сприяють посиленню їх ресурсності 3 метою вирішення як соціальних проблем, так i проблем процесу навчання. Ураховуючи універсальність технології кейсменеджменту та ії основне призначення щодо супроводу здобувача освіти у вирішенні його проблеми від початку спілкування із командою фахівців до вирішення проблеми, можна констатувати ¥ї актуальність в управлінні розвитком інклюзивного освітнього середовища на адаптивних засадах. Разом із тим, необхідно зазначити, що дана технологія тісно пов'язана із соціальною роботою [12]. Тому, провідною ï характеристикою є інтегрованість, бо вона об'єднує освітню і соціальну сферу життєдіяльності особистості. Актуальним, у зв’язку з цим є описання соціального супроводу життєдіяльності здобувача освіти із особливими освітніми потребами.

Розкриємо деякі аспекти нормативного забезпечення реалізації зазначеного. У відповідності до законодавства, безпосередньо спираючись на чинний Закон України «Про соціальну роботу з сім'ями, дітьми та молоддю» (Відомості Верховної Ради України (ВВР), 2001, № 42, ст.213 ), визначимо, що соціальний супровід - це вид соціальної роботи, який спрямований на здійснення соціальних опіки, допомоги та патронажу соціально незахищених категорій дітей та молоді з метою подолання життєвих труднощів, збереження, підвищення їх соціального статусу [8]. Нам імпонує тлумачення цього поняття, яке, на підставі узагальнення наукових джерел, наводиться у посібнику: соціальний супровід передбачає довготривалу роботу, яка спрямована на здійснення індивідуальної соціальної допомоги та підтримки у виді надання комплексних соціальних послуг 3 метою мінімізації складних життєвих обставин, подолання життєвих труднощів, збереження та підвищення соціального статусу клієнта шляхом активізації його ресурсів та найближчого 
оточення [2;12]. Сьогодні соціальний супровід, як провідна технологія індивідуальної соціальної роботи, має назву ведення випадку, або кейсменеджмент. У межах нашого дослідження подана характеристика має сприяти управлінню розвитком інклюзивного освітнього середовища З3СО.

Спираючись на першоджерела, можна зазначити, що розпочинається соціальний супровід з отримання повідомлення/звернення та відкриття випадку [2;5;9]. Це такі показники: характер впливу складних життєвих обставин на стан та потреби дитини з особливими освітніми потребами; стан батьків, осіб, що їх замінюють та їх потенціал щодо задоволення потреб; вплив факторів сім’ї та середовища на задоволення освітніх потреб дитини; тривалість існування проблеми що заважає успішності навчання; усвідомлення учасників освітнього процесу визначеної проблем та готовність до співпраці [8]. У зв'язку із зазначеним вирізняють 4 типи випадку: екстрений, простий, середньої складності, складний.

Безпосередньо в науковій літературі, соціальний супровід поділяють на декілька етапів: підготовчий, етап здійснення та етап завершення (припинення) роботи 3 клієнтом [10]. Наведемо характеристику кожного етапу соціального супроводу. Найважливішим етапом соціального супроводу вважається підготовчий етап. Сутність його полягає в оцінюванні потреб, у нашому випадку освітніх. Провідним завданням даного етапу $\epsilon$ налагодження довірливих, партнерських стосунків між учасниками освітнього процесу; вивчення ситуації дитини/сім'ї і їх оточення; діагностування психосоціальних характеристик дитини/сім’ї і їхнього соціального середовища; формулювання проблеми, визначення пріоритетних потреб, цілей і завдань на основі аналізу зібраної інформації; визначення методів й засобів соціальної допомоги; визначення оціночних критеріїв, що будуть використані під час поточної та заключної оцінки; розробка плану дій; узгодження і документування напрямів $і$ принципів взаємодії соціального працівника і дитини/членів сім’ї - оформлення 
домовленості, угоди, визначення мети, завдань та здійснення планування ведення випадку тощо [2;9]. Не менш важливим є другий етап - здійснення соціального супроводу. Цей процес включає впровадження окремих дій i заходів, передбачених планом. У науковій літературі вважається, що це найголовніший етап надання практичної соціальної допомоги дитині/сім’і, коли одночасно або послідовно (залежно від особливостей випадку) здійснюється втручання (інтервенція) по кожному з визначених планом завдань, проведення заходів стосовно самої дитини, іiї участі в освітньому процесі й комунікації між його учасниками. На цьому етапі до практичної роботи можуть активно залучатися інші фахівці, або організації і спеціалісти, які надають необхідні адресні послуги. Спираючись на першоджерела можна зазначити, що на даному етапі реалізації соціального супроводу: здійснюються безпосередні дії із розв’язання окремих завдань, випробовуються заплановані методи й засоби втручання, оцінюється їх ефективність відносно проміжних результатів, які були заплановані та з’явилися неочікувано. Зазначимо, що при потребі, діяльність коригується: можуть обиратися інші методи, більш доречні до ситуації, якщо вона змінюється [2;10]. Проте завжди в пріоритеті є врахування потреб та можливостей дитини 3 особливими освітніми потребами й узгодження з нею коригувальних дій. Підкреслимо, що під час ведення випадку провідну роль відіграє сам клієнт і вирішальне слово повинно бути за ним. На етапі реалізації соціального супроводу необхідно дотримуватися принципу системного підходу, індивідуалізації допомоги (зосередження роботи на створенні умов, що сприяють розвитку особистості дитини, активному залученні їі до перебігу освітнього процесу шляхом орієнтації на іï резерви та сприяння активізації іï навчальної діяльності через мотиваційні заходи). Третій підсумковий етап надання соціальної допомоги (ведення випадку) клієнту передбачає, в першу чергу, оцінку змін, які відбулися; по-друге, вивчення нових потреб, які з'явилися у дитини в результаті змін, що сталися і вимагають 
задоволення; по-третє, розроблення, якщо це потрібно, нового, додаткового плану соціальної допомоги або припинення роботи 3 дитиною, якщо ситуація це уможливлює; по-четверте, підготовку дитини до згортання соціальної допомоги (соціального супроводу) як складову припинення роботи; по-п’яте, додаткове кураторство як дитини так i ii оточення, якщо це потрібно для профілактики небажаних наслідків і закріплення позитивних змін [2;5;10].

Підкреслимо певну особливість цього етапу. Воно полягає в тому. що дитина має бути підготовленою до припинення активного втручання i воно повинно відбуватися поступово, за рахунок скорочення обсягів допомоги. На даному етапі також відбувається підсумкове (заключне) оцінювання. Воно здійснюється шляхом порівняння стану до надання і після реалізації соціальних послуг, згідно з критеріями, передбаченими на етапі планування соціального супроводу $[2 ; 5 ; 9 ; 10]$.

3 метою запровадження зазначеної технології в практику діяльності 3ЗСО i державних органів управління освітою було розроблено загальну короткострокову програму підвищення кваліфікації та спецкурс «Соціальнопедагогічний супровід осіб з особливими потребами в умовах інклюзивної освіти» для державних службовців, посади яких віднесено до категорій «Б» та «В», і посадових осіб місцевого самоврядування, посади яких віднесено до першої-четвертої категорії посад, з питань забезпечення прав та інтересів осіб 3 інвалідністю. Зазначені освітні продукти розраховані на 30 годин (1 кредит СКТС). Авторами-укладачами програми є 3. В. Рябова, д. пед. н, професор, магістр соціальної роботи, завідувачка кафедри менеджменту освіти та права ЦІПО ДЗВО «Університет менеджменту освіти», Р. В. Козенко, канд. н. $з$ держ. упр., доцент кафедри менеджменту освіти та права ЦІПО ДЗВО «Університет менеджменту освіти», Т. В. Баранцова, урядова уповноважена 3 прав осіб з інвалідністю, аспірантка кафедри менеджменту освіти та права ЦІПО ДЗВО «Університет менеджменту освіти». 
Основні напрями (теми), які охоплює програма: загальні питання та правові аспекти державного управління й місцевого самоврядування в Україні в умовах розвитку громадянського суспільства та впровадження в державі інклюзивної політики; реалізація державної політики у сфері інклюзивної освіти; організація та державний супровід діяльності соціальних служб щодо забезпечення прав та інтересів людей 3 інвалідністю; діджиталізація державного управління в сфері інклюзивної освіти; психологічні аспекти забезпечення прав та інтересів людей з інвалідністю; кризовий менеджмент в діяльності державного службовця. Безпосередньо сутність та технологія кейсменеджменту розкривається під час опанування слухачами теми, що присвячена питанням організації діяльності соціальних служб. Підсумковим контролем є залік, який передбачає проходження тесту. Тест складається 3 шістнадцяти тестових запитань, в основному відкритої форми. Він передбачає оцінювання рівня опанування слухачами змістом основних тематичних напрямів спецкурсу. Наприклад, у тест включено таке запитання: «Сформулюйте визначення інклюзивного навчання та означте поняття «система освітніх послуг» в інклюзивному навчанні». Зазначене запитання передбачає отримання такої відповіді як: «Інклюзивне навчання - система освітніх послуг, гарантованих державою, що базується на принципах недискримінації, врахування багатоманітності людини, ефективного залучення та включення до освітнього процесу всіх його учасників. До освітніх послуг: створення інклюзивних або спеціальних класів для дітей з ООП та надання психолого-педагогічних та корекційно-розвиткових послуг» (https://forms.gle/z1DziQK64qALcdrSA).

Під час рефлексії після завершення спецкурсу ми провели опитування щодо здійснення очікувань та побажань організаторам спецкурсу. Було отримано схвальні відгуки, наприклад, на рисунку 1 представлено відповіді на перше запитання. 


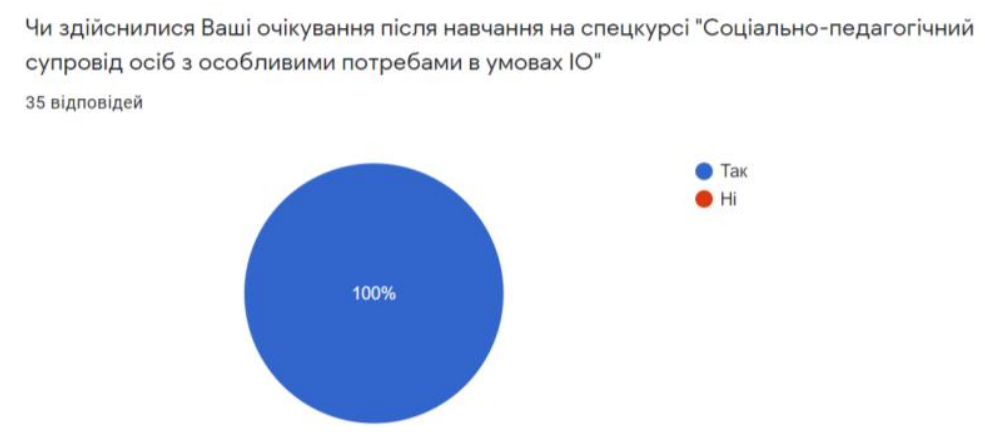

Рис. 1 Відповіді слухачів спецкурсу

Висновки. Перспективи подальших досліджень. Аналіз сутності питання управління розвитком інклюзивного освітнього середовища в закладах загальної середньої освіти на адаптивних засадах дозволяє стверджувати, що використання технології кейс-менеджменту сприятиме позитивній динаміці ефективного залучення та включення до освітнього процесу всіх його учасників 3 врахуванням їх потреб й можливостей. Саме, цілеспрямований вплив на процес спільного навчання, виховання та розвитку здобувачів освіти на основі визначення та задоволення їх освітніх та соціальних потреб забезпечить рівний доступ до якісної освіти усіх учасників освітнього процесу в $33 \mathrm{CO}$. Перспективами подальших наукових розвідок буде створення моделі управління розвитком інклюзивного освітнього середовища в 33 СО та кваліметричної субмоделі оцінювання цього процесу.

\section{Список використаних джерел}

1. Адаптивне управління: міжгалузеві зв'язки, науково-прикладний аспект: кол. монографія / Г. В. Сльникова, Т. А. Борова, 3. В. Рябова та ін.; за заг. і наук. ред. Г. В. Єльникової. Харків: Мачулін, 2017. 440 с.

2. Віцукаєва К.М. Соціальний супровід клієнта: навч. посібн. / К. М. Віцукаєва. - Одеса: Видавництво Букаєв Вадим Вікторович, 2017. - 322 с.

3. Інклюзивне навчання в закладах загальної середньої освіти: керівництво для тренерів [електронний ресурc]. URL: https://cutt.ly/4bc79F8 (дата звернення: вересень 2020)

4. Кейс-менеджмент [електронний ресурc]. URL: https://socfaqtor.wordpress.com/2009/05/14/кейс-менеджмент/ (дата звернення: вересень 2020)

(С) ГО «Школа адаптивного управління соціально-педагогічними системами»

(С) Рябова 3., Баранцова T. 
5. Кейс-менеджмент в социальной работе на местном уровне. Справочник для работников системы здравоохранения, образования и социальной защиты. Детский фонд ООН (ЮНИСЕФ) в Республике Казахстан Астана, 2012 г. -31 с.

6. Про освіту : Закон України від 05 вересня 2017 року № 2145-VIII. URL: https://zakon.rada.gov.ua/laws/show/2145-19 (дата звернення: вересень 2020)

7. Про повну загальну середню освіту : Закон України від 16 січня 2020 року № 463-IX. URL : https://zakon.rada.gov.ua/laws/show/463-20 (дата звернення: вересень 2020)

8. Про соціальну роботу з сім'ями, дітьми та молоддю»: Закон України від від 17.01.2019 № 2558-III. URL: https://zakon.rada.gov.ua/laws/show/ru/2558-14?lang=uk (дата звернення: вересень 2020)

9. Савчук О. Робота з випадком // О. Савчук, К. Сініцина Всеукраїнська благодійна організація «Всеукраїнська Мережа ЛЖВ» 2013 - 60 с.

10. Соціальний супровід. [електронний ресурc]. URL: https://cutt.ly/Nbc4PKg (дата звернення: вересень 2020)

11. Case Management Society of America. URL : https://cmsa.org/ (дата звернення: вересень 2020)

12. Mirowska M. Case management na kierunku praca socjalna jako przykład nowoczesnego modelu kształcenia studentów i tranzycji z edukacji na rynek pracy. W: W. Duda, J. Górna, M. Nowacka (red.). Poradnictwo zawodowe w procesie tranzycji. Częstochowa, 2017. S. 211-219

\section{References}

1. Adaptyvne upravlinnia: mizhhaluzevi zviazky, naukovo-prykladnyi aspekt: kol. monohrafiia / H. V. Yelnykova, T. A. Borova, Z. V. Riabova ta in.; za zah. i nauk. red. H. V. Yelnykovoi. Kharkiv: Machulin, 2017. 440 s.

2. Vitsukaieva K.M. Sotsialnyi suprovid kliienta: navch. posibn. / K. M. Vitsukaieva. — Odesa: Vydavnytstvo Bukaiev Vadym Viktorovych, 2017. - 322 s.

3. Inkliuzyvne navchannia $\mathrm{v}$ zakladakh zahalnoi serednoi osvity: kerivnytstvo dlia treneriv [elektronnyi resurs]. URL: https://cutt.ly/4bc79F8 (data zvernennia: veresen 2020)

4. Keis-menedzhment [elektronnyi resurs]. URL: https://socfaqtor.wordpress.com/2009/05/14/keis-menedzhment/ (data zvernennia: veresen 2020)

5. Keis-menedzhment v sotsyalnoi rabote na mestnom urovne. Spravochnyk dlia rabotnykov systemы zdravookhranenyia, obrazovanyia y sotsyalnoi zashchytb. Detskyi fond OON (IuNYSEF) v Respublyke Kazakhstan Astana, 2012 h. - 31 s.

6. Pro osvitu : Zakon Ukrainy vid 05 veresnia 2017 roku № 2145-VIII. URL: 
https://zakon.rada.gov.ua/laws/show/2145-19 (data zvernennia: veresen 2020)

7. Pro povnu zahalnu seredniu osvitu : Zakon Ukrainy vid 16 sichnia 2020 roku № 463-IX. URL : https://zakon.rada.gov.ua/laws/show/463-20 (data zvernennia: veresen 2020)

8. Pro sotsialnu robotu z simiamy, ditmy ta moloddiu»: Zakon Ukrainy vid vid 17.01.2019 № 2558-III. URL: https://zakon.rada.gov.ua/laws/show/ru/255814?lang=uk (data zvernennia: veresen 2020)

9. Savchuk O. Robota z vypadkom // O. Savchuk, K. Sinitsyna Vseukrainska blahodiina orhanizatsiia «Vseukrainska Merezha LZhV» 2013 - 60 s.

10. Sotsialnyi suprovid. [elektronnyi resurs]. URL: https://cutt.ly/Nbc4PKg (data zvernennia: veresen 2020)

11. Case Management Society of America. URL : https://cmsa.org/ (data zvernennia: veresen 2020)

12. Mirowska M. Case management na kierunku praca socjalna jako przykład nowoczesnego modelu kształcenia studentów i tranzycji z edukacji na rynek pracy. W: W. Duda, J. Górna, M. Nowacka (red.). Poradnictwo zawodowe w procesie tranzycji. Częstochowa, 2017. S. 211-219

РЯБОВА ЗОЯ,

доктор педагогических наук, профессор, заведующая кафедрой менеджмента образования и права ЦИПО ДЗВО «Университет менеджмента образования», г. Киев, Украина.,

БАРАНЦОВА ТАТЬЯНА, правительственная уполномоченная по правам людей с инвалидностью, аспирантка кафедры менеджмента образования и права ЦИПО ДЗВО «Университет менеджмента образования», г. Киев, Украина.,

\section{АДАПТИВНЫЕ ОСНОВЫ УПРАВЛЕНИЯ РАЗВИТИЕМ ИНКЛЮЗИВНОЙ ОБРАЗОВАТЕЛЬНОЙ СРЕДЫ В УЧРЕЖДЕНИЯХ ОБЩЕГО СРЕДНЕГО ОБРАЗОВАНИЯ}

Аннотация. Статья посвящена вопросам управления развитием инклюзивной образовательной среды в учреждениях общего среднего образования на адаптивных основах. В тексте приводятся сущностные характеристики инклюзивной образовательной среды, отмечается, что в основе создания такой среды в учреждении общего среднего образования положено определение и построение образовательного процесса 3 учетом индивидуальных потребностей и возможностей каждого соискателя 
образования, в частности учащихся с особыми образовательными потребностями. Обосновывается, что в условиях обеспечения равного доступа к качественному образованию, данный вопрос является актуальным, что усиливается как международными обязательствами, так и нормативными документами. Авторами отмечается, что развитие инклюзивной образовательной среды в учреждениях общего среднего образования предусматривает положительную динамику привлечения и включение в образовательный процесс всех его участников. Также, приводится авторское толкование понятия «управление развитием инклюзивного образовательного среды в учреждениях общего среднего образования на адаптивных основах»: это целенаправленное воздействие на процесс совместного обучения, воспитания и развития соискателей образования на основе эффективного привлечения и включение в образовательный процесс всех его участников с учетом их потребностей и возможностей. Определяется, что перспективной технологией управления развитием инклюзивной образовательной среды в учреждениях общего среднего образования на адаптивных основах является технология кейс-менеджмента. Описывается ее сущность, как определенного процесса, который объединяет оценку, планирование, отслеживание успеваемости и активное привлечение к течению образовательного процесса его участников, отвечает определённым потребностям соискателя образования, как здоровья, так и его социального благополучия. Также, статья включает описание сущности и этапов социального сопровождения. Авторами приводятся две образовательные программы, овладение содержанием которых будет способствовать успешному управлению развитием инклюзивного образовательного среды в учреждениях общего среднего образования на адаптивных основах.

Ключевые слова: управление развитием, инклюзивная образовательная среда, адаптивные основы, кейс-менеджмент, социальное сопровождение. 


\title{
RYABOVA ZOYA,
}

Doctor of Pedagogical Sciences, Professor, Head of the Department of Education Management and Law TsIPO DZVO "University of Education Management", Kyiv, Ukraine

\section{BARANTSOVA TETYANA,}

Government Commissioner for the Rights of Persons with Disabilities, Postgraduate Student, Department of Education Management and Law, Center for Educational Management, Kyiv, University of Education Management, Kyiv, Ukraine

\section{ADAPTIVE PRINCIPLES OF MANAGEMENT OF INCLUSIVE EDUCATIONAL ENVIRONMENT DEVELOPMENT IN GENERAL SECONDARY EDUCATION INSTITUTIONS}

\begin{abstract}
The article is devoted to the issues of managing the development of inclusive educational environment in general secondary education institutions on an adaptive basis. The text presents the essential characteristics of an inclusive educational environment, it is noted that the creation of such an environment in a general secondary education institution is based on the definition and consideration in the educational process of individual needs and opportunities of each student, including students with special educational needs. It is substantiated that in the conditions of ensuring equal access to quality education, this issue is relevant, which is reinforced by both international obligations and regulations. The authors note that the development of an inclusive educational environment in general secondary education provides some positive dynamics of involvement and inclusion in the educational process of all its participants. Also, the author's interpretation of the concept of "management of inclusive education in general secondary education on an adaptive basis: it is a purposeful impact on the process of joint learning, education and development of students through effective involvement and inclusion in the educational process of all its participants. and opportunities. It is determined that a promising technology for managing the development of an inclusive educational environment in general secondary education institutions on an adaptive basis is case management technology. Its essence is given, as it is a certain process that combines assessment, planning, tracking the success of learning and active involvement in the educational process, which meets the needs of both the health of the learner and his social well-being. Also, the article includes a description of the nature and stages of social support. The authors present two educational programs, the content of which will contribute to the successful management of the development of an inclusive educational environment in general secondary education institutions on an adaptive basis.
\end{abstract}

Key words: development management, inclusive educational environment, adaptive principles, case management, social support.

\footnotetext{
(C) Украӥнська інженерно-педагогічна академія

(С) ГО «Школа адаптивного управління соціально-педагогічними системами»

(C) Рябова 3., Баранцова T.
} 